\title{
THE APEC INTEGRATED COMPETITIVE FORCE INDEX
}

\author{
Mykola Palinchak', Olena Zayats², Viktoria Bokoch ${ }^{3}$
}

\begin{abstract}
The number of actors that affect the distribution of the competitive force in the global economy is growing, and the spheres of economic competition or cooperation are expanding to build up the competitive force. The article emphasizes the significant impact of international economic integration on the sustainable economic development of the world economy. It also shows that the study of the competitive force of interstate integration groupings is highly relevant today, as international economic integration plays a fundamental role in the development of trade and competitive relations between countries. The paper offers the methodology for competitiveness grouping of Member States of the international integration groupings in order to assess the global competitive force of trade and economic groupings in the world economy. The purpose is to investigate the Integrated Competitive Force Index of Asia-Pacific Economic Cooperation (APEC) 2019 in order to analyze the attractiveness of APEC in terms of the global competitive force. It is also important to determine the attractiveness of APEC competitive environment according to 12 criteria on the basis of the research, which, in turn, allows for a better understanding and ranking of interstate integration groupings according to their competitive forces. Result. Based on the data of the Global Competitiveness Report 2019 on the competitiveness of Asia-Pacific Economic Cooperation Member States (APEC), the Integrated Competitive Force Index of APEC as an interstate integration grouping has been calculated. The Index will help to assess economic integration or disintegration processes in the global economy. The article proves the necessity of the annual integrated competitive force ranking of international integration groupings. Practical implications. The introduction of the new Integrated Competitive Force Index of interstate integration groupings will help competition policymakers to decide which processes of economic integration or disintegration should be preferred in order to build up their competitive force in the global economy.
\end{abstract}

Key words: the Global Competitiveness Index of a country, APEC Member States, international economic integration, the competitive force of an interstate integration grouping, the APEC competitive status in the global economy.

JEL Classification: F00, F01, F02, F15

\section{Introduction}

The competitiveness of commodity, enterprise, industry, country and geographical regions of the world economy has been given wide coverage in the contemporary international economic literature. However, when examining the competitiveness of participants in global competition, we noticed that the issues of the integrated competitive force of international integration groupings are not covered at all by modern scholars. There is no definition of the competitiveness of interstate integration groupings. The Integrated Competitive Force Index of these groupings, which would characterize and evaluate the state, effectiveness of cooperation between the Member

\footnotetext{
Corresponding author:

${ }^{1}$ Uzhorod National University, Ukraine.

E-mail: palinchakmm@gmail.com

ORCID: https://orcid.org/0000-0002-9990-5314

${ }^{2}$ Uzhorod National University, Ukraine.

E-mail: olena.zayats@uzhnu.edu.ua

ORCID: https://orcid.org/0000-0001-9904-8706

${ }^{3}$ Uzhorod National University, Ukraine.

E-mail: viktoriya.bokochh@uzhnu.edu.ua

ORCID: https://orcid.org/0000-0002-0636-2032
}

States and dynamics of economic integration and disintegration processes, has not been calculated. In our view, it is necessary to investigate the competitive force of international integration groupings, since they are important actors of the global economy and significantly affect the international competitive environment and the results obtained will have theoretical and practical value.

This study will enhance knowledge in this field of economics by grouping the 21 APEC Member States' global competitiveness indices according to 12 criteria and identifying the new quantitative and qualitative Integrated Competitive Force Index of an international integration grouping. To reach this objective, we will 
define the Integrated Competitive Force Index as the average of the individual points of APEC Member States in 2019.

\section{Identification of unexplored parts of the general problem}

Despite considerable attention of scholars (Porter, 1990; Krugman, 1994, 1996; Aiginger, 2006, 2015; Hellwig, 2019; Wolf, 2020), governments (Council on Competitiveness USA, 2020), international and nongovernmental organizations (World Economic Forum, 2019; World Bank Group, 2020; International Institute for Management Development - IMD, 2020) and a variety of the competitive force criteria and indices for ranking national economies, the existing studies consider only the indices of the global competitive force in terms of countries and geographical regions. However, they do not calculate the index of the global competitive force of international integration groupings. Meanwhile, it is extremely relevant given the current globalization processes in competitive relations between all actors in the world economy. The novelty of our study lies in the comparative analysis of the five largest interstate integration groupings from the perspective of their competitive force.

\section{Results}

\subsection{Competitive force of an international integration grouping}

Given the development of contemporary globalization, transnationalization, regionalization, it could be argued that the interstate borders are becoming more transparent. American theorist R. Folk (1999) says that states, under the influence of border blurring, will no longer be the dominant force on the world stage.

N. Reznikova (2013), after a thorough analysis, proves that globalization brings about a new version of reality, in which countries gradually lose the right to determine their place in the economic arena, being prisoners of ready-made rules that are coordinated by international economic organizations and institutions initiated by the world's leading powers. Globalization as an economic process involves all national economies and international integration groupings. Not only countries but also regional integration groupings play a leading role in the globalization processes (EU, USMCA, APEC, ASEAN, MERCOSUR etc.). This is attributed to the fact that the globalization of the economic activity requires the reduction or elimination of restrictions on international trade, foreign investment and international financial transactions.

Interstate integration groupings were established primarily at the initiative of the most powerful countries in the world, in order to increase their economic and competitive power and force in the global economy. Therefore, the competitive force of interstate integration groupings in the current context of globalization of competitive relations gains a great theoretical and practical significance. Understanding the role of an international integration grouping in competition on the international market will be equally valuable both for the Member State of the interstate integration grouping and for the competition policy of the respective grouping as a whole, since it would determine how the competitive force of an international integration grouping is established and maintained.

The strengthening of the competitive position of the international integration groupings was relatively recent. However, today they not only mediate relations between Member States and interstate economic relations, but also act as full actors of the global economy. In this regard, it is necessary to emphasize the significant changes in the global competitive environment of the world economy, which is directly related to the transformational nature of today's driving competitive processes. We argue that the study of the competitive force limiting to a country in the global economy does not fully correspond to the current development of the world economy, its challenges and trends. It is necessary to measure the competitive force of international integration groupings, as international economic integration has historically helped countries to achieve common goals. Through cooperation, countries enhanced the integration of the economy and changed their competitive force in the global economy. Today, many countries view themselves as outsiders and face uncertainty about economic integration or disintegration. Others doubt whether they can meet the goals of sustainable economic development of interstate integration groupings.

The current market economy is accompanied by building up the competitive force, which is one of the main goals not only of individual entities, countries, but also of the international integration groupings. Why we focus on the competitive force of the largest international integration groupings? Because they unite countries and jointly cooperate with the global competitive forces of Member States. They also play an important role in shaping the global economy and international competition, intensively affect the development of the world economic relations both among the Member States of the international integration groupings and among the groupings as a whole and countries that are not members of international integration groupings.

The use of the term "global competitive force" regarding the interstate integration grouping is related to its perception as a subject of the world market environment; therefore, the national competitive force of a Member State is an object. We consider the asymmetric distribution of the competitive potential of the Member States as the source of the global competitive force of the interstate integration groupings. 
The competitive force of an international integration grouping is the main criterion of its economic efficiency as a subject of a global competitive economy, which is provided by the joint competitive advantages of Member States in the struggle for markets, resources, for a place in the world market, customers, and for profit, which determines the output growth and the ability to develop on an innovative basis and win in global competition.

The competitive force of an international integration grouping can act as an impetus to increase the global competitive force of a country that is planning to integrate into the grouping. In each case, the timely response of a global competitor to changes will be important for the competition policy of the country or interstate integration grouping. The challenges of the economic turbulence of 2020 caused by the COVID-19 pandemic are likely to shake the foundations of global economic structures and national economies will undergo significant changes. Under such conditions, almost all actors in the global economy face a fundamental question: will the COVID-19 pandemic affect economic and competitive reforms in international integration groupings, which in turn may lead to changes of the world's facade?

Currently, interstate integration groupings are regaining their resilience and continue to be geoeconomic leaders. Through joint activities of Member States, they work to strengthen cooperation and develop joint strategies for the recovery of both national economies and the economies of international integration groupings; therefore, they significantly affect the global competitive environment. In our view, the special role of international integration groupings in the process of distribution of global competitive force between countries and, accordingly, their positioning in international rankings cannot be disputed. It highlights the need to monitor and rank interstate integration groupings according to the competitive force the same way as national economies of individual countries.

\subsection{The global competitive force of APEC Member States}

Before proceeding directly to the calculation of the APEC Integrated Competitive Force Index, we need to consider the place of the Member States in the global competitiveness ranking according to the World Economic Forum 2019.

We will calculate the APEC Integrated Competitive Force Index based on the Member States data of The Global Competitiveness Report 2019 (Table 1).

The table shows that APEC Member States differ significantly in terms of global competitive forces. It should be noted that the best results in terms of the competitiveness of all Member States are presented according to the criterion of macroeconomic stability. According to this indicator, their points are virtually identical, and are closer to the maximum than most of all the criteria of the global competitive force. If we consider the indicators of the Global Competitiveness Index of the APEC Member States in general, the Member States are placed in the following order: Singapore - 1 (1/141), the United States - 2 (2/141), Hong Kong, China - 3 (3/141), Japan - 4 (6/141), Taiwan, China - 5 (12/141), Republic of Korea - 6 (13/141), Canada - 7 (14/141), Australia - 8 (16/141), New Zealand - 9 (19/141), Malaysia - $10(27 / 141)$, China - 11 (28/141), Chile - 12 (33/141), Thailand - 13 (40/141), Russia-14(43/141), Mexico-15(48/141), Indonesia16 (50/141), Brunei Darussalam - 17 (56/141), the Philippines - 18 (64/141), Peru - 19 (65/141), Viet Nam-20(67/141), Papua New Guinea-21 (122/141).

Among the countries of the said international integration grouping there are world leaders: Singapore, which tops the ranking, and the United States, which in 2019 ranked second, although in 2018 the United States topped the ranking of competitive economic development of the world economy. It should be noted that the difference between the positions of the United States and Singapore is insignificant: Singapore 84.8 points, the USA -83.7 points. In 2018 , the United States (85.6) ranked first among 140 countries, and Singapore (83.5) ranked second (World Economic Forum 2018, 2019).

No country in the world is competitive in all sectors of the economy. Cooperation of countries within international integration groupings contributes to the differentiation of the global competitive force of Member States, as we can see in the case of APEC. In this regard, it is possible to assert that assessment of the competitive force is relevant for determining the development areas of Member States of the international integration grouping's Member States, the establishment of common competition policy and initiating the interstate and interunion dialogue. Basing research on Member States' Global Competitiveness Index of the international integration groupings, there are possible risks of taking the wrong path. On the other hand, we consider that such an approach will deepen the understanding of international economic integration.

\subsection{The APEC Integrated Competitive Force Index}

The development of the Integrated Competitive Force Index of international integration groupings will provide a basis for the establishment of the competition policy of the international integration groupings and will identify their further actions to build up the competitive force of the grouping as well as strategic decisions of Member States regarding participation in the international economic integration and disintegration. 
Table 1

\begin{tabular}{|c|c|c|c|c|c|c|c|c|c|c|c|c|c|}
\hline $\begin{array}{c}\text { APEC } \\
\text { MEMBER- } \\
\text { STATES }\end{array}$ & 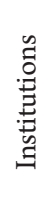 & 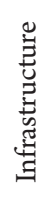 & 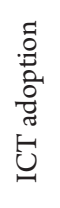 & 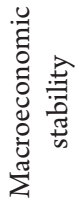 & 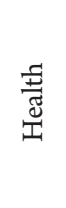 & $\frac{a}{\overline{\vec{n}}}$ & 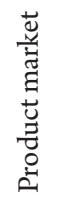 & 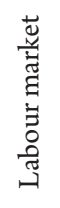 & 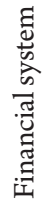 & 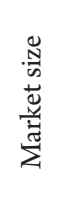 & 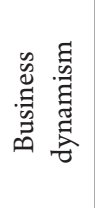 & 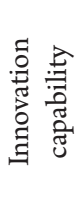 & 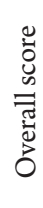 \\
\hline Australia & 74 & 78 & 73 & 100 & 99 & 81 & 70 & 69 & 86 & 72 & 75 & 70 & 79 \\
\hline Brunei Darussalam & 58 & 71 & 76 & 74 & 86 & 66 & 61 & 64 & 51 & 37 & 59 & 34 & 61 \\
\hline Canada & 75 & 81 & 69 & 100 & 97 & 81 & 65 & 77 & 86 & 77 & 76 & 75 & 80 \\
\hline Chile & 64 & 75 & 61 & 100 & 93 & 70 & 68 & 63 & 80 & 63 & 64 & 41 & 70 \\
\hline China & 55 & 78 & 71 & 98 & 87 & 64 & 57 & 59 & 72 & 100 & 65 & 64 & 73 \\
\hline Hong Kong, China & 77 & 94 & 88 & 100 & 100 & 77 & 79 & 74 & 90 & 71 & 75 & 62 & 82 \\
\hline Indonesia & 58 & 67 & 61 & 90 & 72 & 64 & 58 & 58 & 64 & 82 & 69 & 37 & 65 \\
\hline Japan & 71 & 91 & 87 & 94 & 100 & 74 & 73 & 71 & 86 & 87 & 76 & 79 & 82 \\
\hline Republic of Korea & 66 & 92 & 93 & 100 & 99 & 74 & 56 & 63 & 84 & 79 & 70 & 79 & 80 \\
\hline Malaysia & 69 & 78 & 72 & 100 & 81 & 73 & 65 & 70 & 85 & 73 & 75 & 55 & 75 \\
\hline Mexico & 48 & 72 & 55 & 98 & 82 & 58 & 58 & 56 & 62 & 81 & 66 & 44 & 65 \\
\hline New Zealand & 79 & 76 & 78 & 100 & 91 & 82 & 72 & 77 & 77 & 54 & 76 & 61 & 77 \\
\hline Papua New Guinea & 46 & 42 & 29 & 66 & 40 & 37 & 55 & 57 & 54 & 36 & 58 & 35 & 46 \\
\hline Peru & 49 & 62 & 46 & 100 & 95 & 60 & 57 & 59 & 61 & 62 & 56 & 33 & 62 \\
\hline Philippines & 50 & 58 & 50 & 90 & 66 & 64 & 58 & 65 & 68 & 71 & 66 & 38 & 62 \\
\hline Russia & 53 & 74 & 77 & 90 & 69 & 68 & 53 & 61 & 56 & 84 & 63 & 53 & 67 \\
\hline Singapore & 80 & 95 & 87 & 100 & 100 & 79 & 81 & 81 & 91 & 72 & 76 & 75 & 85 \\
\hline Taiwan, China & 69 & 87 & 82 & 100 & 94 & 76 & 66 & 73 & 88 & 75 & 73 & 80 & 80 \\
\hline Thailand & 55 & 68 & 60 & 90 & 89 & 62 & 53 & 63 & 85 & 76 & 72 & 44 & 68 \\
\hline United States & 71 & 88 & 74 & 100 & 83 & 82 & 69 & 78 & 91 & 100 & 84 & 84 & 84 \\
\hline Viet Nam & 50 & 66 & 69 & 75 & 81 & 57 & 54 & 58 & 64 & 72 & 57 & 37 & 62 \\
\hline
\end{tabular}

Source: Compiled by the author based on The Global Competitiveness Report 2019 by the World Economic Forum

To calculate the APEC Integrated Competitive Force Index, we will analyze the Member States according to 12 global competitive force criteria. The value of the Integrated Competitive Force Index of the interstate integration grouping will be defined as the average value of individual points of APEC 2019 Member States. Despite the methodological simplicity, the proposed calculation of the competitive force of international integration groupings is a comprehensive assessment of the results of the Member States' international economic integration. According to our calculations, the APEC Integrated Competitive Force Index is 72 points out of 100 possible (Figure 1 ).

The results of a comprehensive integrated assessment of the competitive force of 21 APEC Member States demonstrate a high overall competitive force index of the grouping, indicating the APEC's impact on global competitive processes. The APEC Integrated Competitive Force Index can be used both as an indicator of the separate international integration grouping's development and as a global criterion for the effectiveness of interstate integration groupings in the transformation of international competitive relations.

3.4. APEC in the ranking of the largest interstate integration groupings according to their competitive force. The proposed method of measuring the competitive force of international integration groupings points to the obvious need to form a rating of trade and competitive groupings on its basis to compare them in terms of the competitive force. We believe that the quantitative assessment of the integrated competitive force of integration groupings should be determined annually for the purpose of monitoring and analyzing the processes of economic integration and disintegration. Given the diversity and uniqueness of each international integration grouping, finding a universal comparison indicator that would cover all factors, criteria and the degree of their impact on the competitive force of an international integration grouping is simply not possible.

The ranking of the integrated competitive force of the largest integration groupings will be based on a comparison of the integrated competitive force indices of USMCA, EU, APEC, ASEAN and MERCOSUR. Thus, it will be appropriate to compare not only the general assessment of competitive force, but also to assess in terms of the ranking criteria of countries and, accordingly, the interstate integration groupings that unite them (Table 2).

The best results of all five international integration groupings are presented according to the criterion of macroeconomic stability; on this indicator, their points are closer to the maximum than all criteria of the competitive force. The table shows that international 


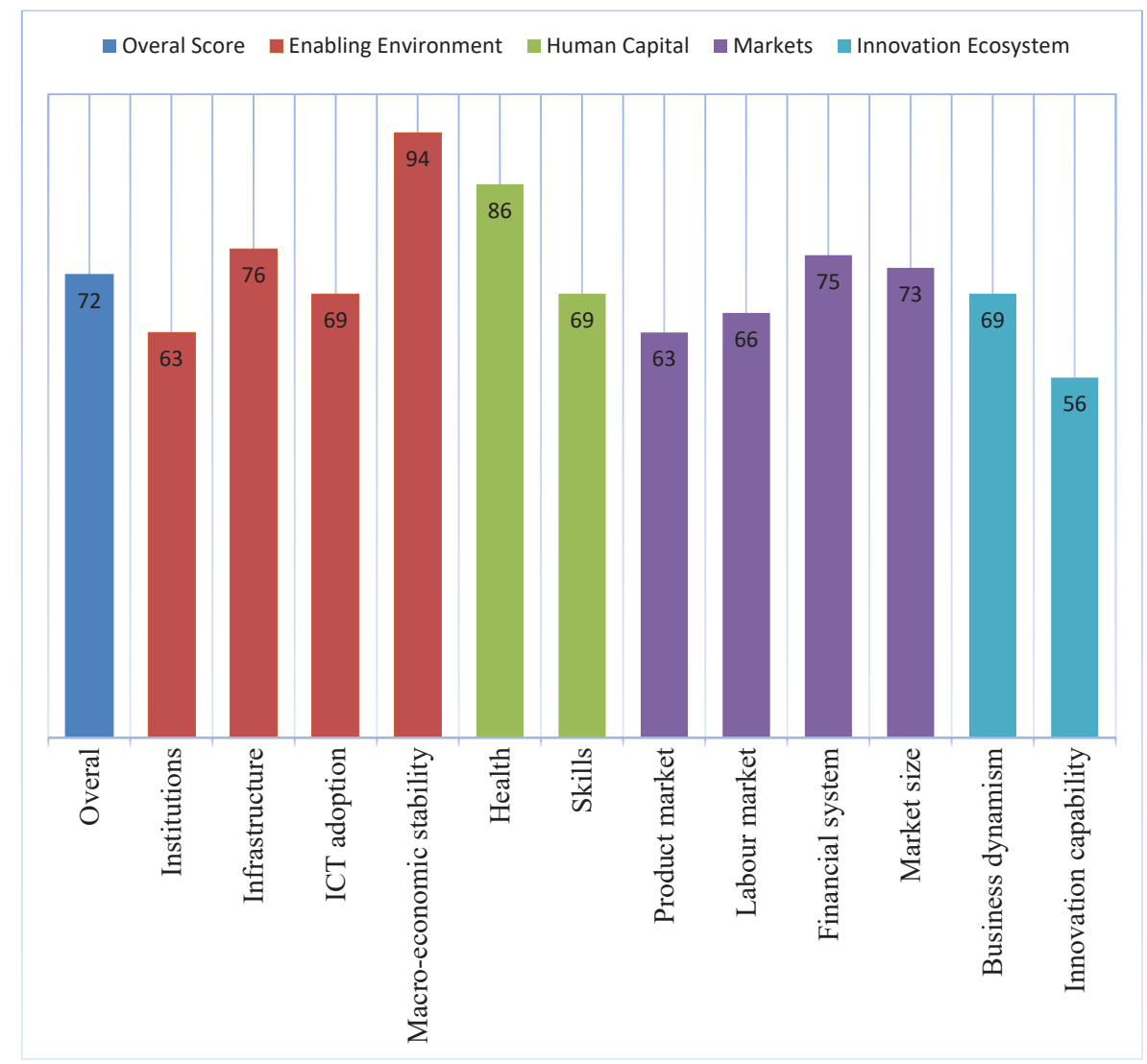

Figure 1. The APEC Integrated Competitive Force Index, 2019

Source: Calculated by the author based on The Global Competitiveness Report 2019 by the World Economic Forum

Table 2

Competitive force of international integration groupings, 2019

\begin{tabular}{|c|c|c|c|c|c|c|c|c|c|c|}
\hline \multirow{2}{*}{$\begin{array}{l}\text { INTEGRATION } \\
\text { GROUPING }\end{array}$} & \multicolumn{2}{|c|}{ USMCA } & \multicolumn{2}{|c|}{ EU } & \multicolumn{2}{|c|}{ APEC } & \multicolumn{2}{|c|}{ ASEAN } & \multicolumn{2}{|c|}{ MERCOSUR } \\
\hline & $\begin{array}{l}\text { Rank } \\
2019\end{array}$ & Score & $\begin{array}{l}\text { Rank } \\
2019\end{array}$ & Score & $\begin{array}{l}\text { Rank } \\
2019\end{array}$ & Score & $\begin{array}{l}\text { Rank } \\
2019\end{array}$ & Score & $\begin{array}{l}\text { Rank } \\
2019\end{array}$ & Score \\
\hline \multicolumn{11}{|c|}{ ENABLING ENVIRONMENT } \\
\hline Institutions & 2 & 64 & 1 & 65 & 3 & 63 & 5 & 51 & 4 & 56 \\
\hline Infrastructure & 2 & 80 & 1 & 82 & 3 & 76 & 5 & 66 & 4 & 69 \\
\hline ICT adoption & 3 & 66 & 1 & 72 & 2 & 69 & 5 & 60 & 4 & 63 \\
\hline Macro-economic stability & 1 & 99 & 2 & 96 & 3 & 94 & 5 & 66 & 4 & 85 \\
\hline \multicolumn{11}{|c|}{ HUMAN CAPITAL } \\
\hline Health & 2 & 88 & 1 & 90 & 3 & 86 & 4 & 82 & 5 & 77 \\
\hline Skills & 2 & 74 & 1 & 75 & 3 & 69 & 4 & 62 & 5 & 62 \\
\hline \multicolumn{11}{|c|}{ MARKETS } \\
\hline Product market & 1 & 64 & 3 & 61 & 2 & 63 & 5 & 51 & 4 & 59 \\
\hline Labour market & 1 & 70 & 2 & 66 & 3 & 66 & 5 & 55 & 4 & 64 \\
\hline Financial system & 1 & 80 & 3 & 70 & 2 & 75 & 5 & 58 & 4 & 69 \\
\hline Market size & 1 & 86 & 5 & 61 & 2 & 73 & 3 & 73 & 4 & 64 \\
\hline \multicolumn{11}{|c|}{ INNOVATION ECOSYSTEM } \\
\hline Business dynamism & 1 & 76 & 3 & 66 & 2 & 69 & 5 & 57 & 4 & 62 \\
\hline Innovation capability & 1 & 67 & 2 & 59 & 3 & 56 & 5 & 38 & 4 & 43 \\
\hline \multicolumn{11}{|c|}{ GLOBAL COMPETITIVENESS INDEX 2019} \\
\hline 2019 & 1 & 76 & 2 & 72 & 3 & 72 & 4 & 65 & 5 & 59 \\
\hline
\end{tabular}

Source: Calculated by the author based on The Global Competitiveness Report 2019 by the World Economic Forum 


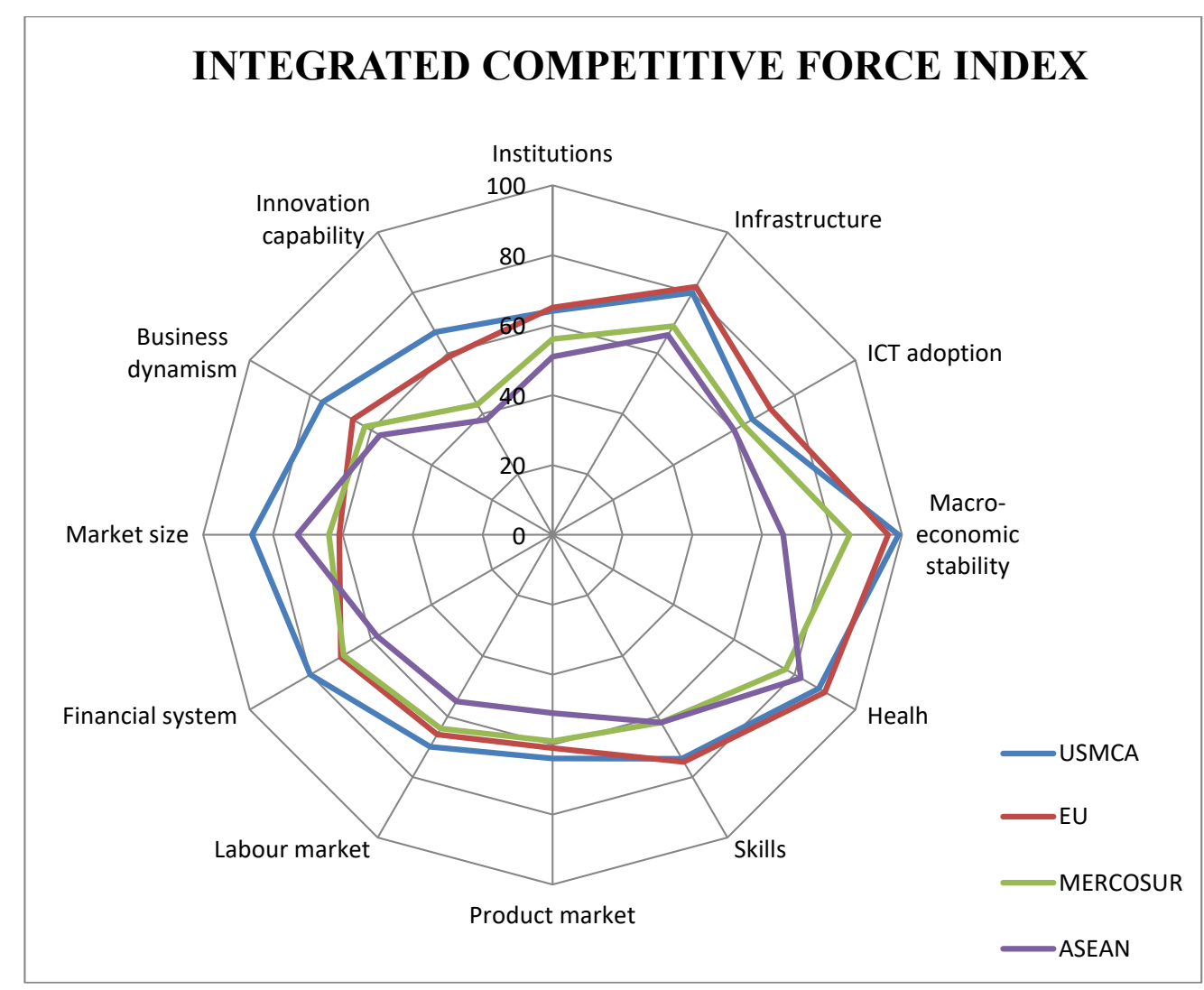

Figure 2. Integrated Competitive Force Index USMCA, EU, APEC, ASEAN, MERCOSUR

Source: Calculated by the author based on The Global Competitiveness Report 2019 by the World Economic Forum

integration groupings differ in their level of the competitive force. It should be noted that a comparison of the assessments of the integrated competitive force of USMCA, the European Union, the Association of Southeast Asian Nations, APEC and MERCOSUR gives us ground to conclude that USMCA is a leader among interstate integration groupings in the global economy in terms of the competitive force.

However, according to the criteria of the institution, infrastructure, implementation of information technologies, health and qualifications, the European Union has the highest points compared to USMCA, APEC, ASEAN and MERCOSUR. Thus, USMCA has the highest overall points, but not by all criteria of the competitive force. APEC, the Association of Southeast Asian Nations and MERCOSUR do not hold leadership positions by any of the criteria.

The data of the Integrated Competitive Force Index in general show that interstate integration groupings are placed in the following order: USMCA - ranks first among 5 groupings, EU - 2/5, APEC - 3/5, ASEAN 4/5 and MERCOSUR - 5/5 (Figure 2).

\section{Conclusions}

Firstly, at the present stage of development of the world economy it is insufficient to measure the global competitive force only in terms of a country and geographical region. Despite the variety of methods of intercountry comparisons according to the level of the global competitive force, there is no distinguishing of competitive forces of other equally important actors of the global economy, such as interstate integration groupings. As of 2020, the scholars do not single out or measure the competitive force of interstate integration groupings.

Secondly, by identifying the objective and most compelling reasons for the necessity to calculate the Integrated Competitive Force Index of interstate integration groupings, we quantified the competitive force of Asia-Pacific Economic Cooperation, and compared the data in terms of 12 criteria.

Thirdly, according to the Integrated Competitive Force Index, the world leader among the investigated interstate integration groupings is USMCA - 76 out of 100 possible points; EU - 72/100; APEC - 72/100; ASEAN - 65/100; MERCOSUR - 59/100. 


\section{References:}

Aiginger, K. (2006). Competitiveness: From a Dangerous Obsession to a Welfare Creating Ability with Positive Externalities. Journal of Industry Competition and Trade, 6(2), 161-177. doi: 10.1007/s10842-006-9475-6

Aiginger, K. \& Johanna, V. (2015). Competitiveness: from a misleading concept to a strategy supporting Beyond GDP goals. Competitiveness Review, 25, 497-523. doi: http://dx.doi.org/10.1108/CR-06-2015-0052

Council on Competitiveness USA (2020). Innovatioun Leaders Propose Nine Pillars for Competing in the Next Economy. Available at: https://www.compete.org/news/12-general-news/3408-press-release-nine-pillars-forcompeting-in-the-next-economy

IMD World Competitiveness Center (2020). IMD World Competitiveness ranking 2020. Available at: https://www.imd.org/wcc/world-competitiveness-center-rankings/world-competitiveness-ranking-2020/ (accessed 02 June 2020).

Falk, R. (1999). World Orders, Old and New. - "Current History".

Hellwig, M. (2019). Competitiveness as doublespeak. Available at: http://foolsgold.international/interviewmartin-hellwig-competitiveness-doublespeak/ (accessed 20 June 2020).

Krugman, P. (1994). Competitiveness: A Dangerous Obsession. Foreign affairs, 73, 28-44. Available at: https://pdfs.semanticscholar.org/4c16/a551a1761792f06edcee31f2b6dbd2636566.pdf (accessed 18 June 2020). Krugman, P. (1996). Making sense of the competitiveness debate. Oxford review of economic policy, 12, 17-25. Available at: https://www.staff.ncl.ac.uk/david.harvey/ACE2006/Competition/KrugmanComp.pdf (accessed 22 June 2020).

Porter, M. (1990). The Competitive Advantage of Nations. Harvard Business Review, 68, 73-91. Available at:

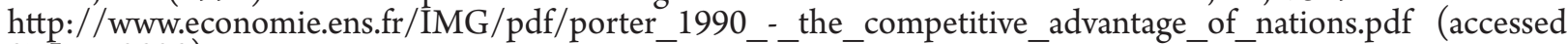
07 June 2020).

Reznikova, N. (2013). Global Economic Interdependence: The Contemporary Paradigm and Determinants of Modification. Kiev: Vistka.

Wolf, M. (2020). The Competitiveness Files. Available at: https://www.taxjustice.net/2020/01/06/thecompetitiveness-files-martin-wolf/ (accessed 12 June 2020).

World Bank Group. Doing Business 2020. Available at: http://documents1.worldbank.org/curated/ en/688761571934946384/pdf/Doing-Business-2020-Comparing-Business-Regulation-in-190-Economies.pdf (accessed 28 June 2020).

World Economic Forum (2018). The Global Competitiveness Report 2018. Available at: http://www3.weforum.org/ docs/GCR2018/05FullReport/TheGlobalCompetitivenessReport2018.pdf (accessed 03 June 2020).

World Economic Forum (2019). The Global Competitiveness Report 2019. Available at: http://www3.weforum.org/ docs/WEF_TheGlobalCompetitivenessReport2019.pdf (accessed 05 June 2020). 